\title{
The Need for a Family Policy That Fosters Family as an Institution
}

\author{
Josu Ahedo Ruiz \\ UNIR-Universidad Internacional de La Rioja, Logroño, Spain \\ Email: Josu.ahedo@unir.net
}

Received 29 October 2014; revised 20 November 2014; accepted 16 December 2014

Copyright (C 2015 by author and Scientific Research Publishing Inc.

This work is licensed under the Creative Commons Attribution International License (CC BY). http://creativecommons.org/licenses/by/4.0/

(c) (i) Open Access

\begin{abstract}
The 20th anniversary of the international year of the family has led to the General Assembly of the United Nations to ask for a review of family policies adopted by each country to achieve three objectives: eradication of poverty, full employment and social integration. However, an X-ray of the situation of the family according to the data provided by The Word Family Map (2013) says that it has decreased the rate of birth and marriage, while it has increased the cohabitation and births in other than the traditional family forms such as single-parent families. This article advocates the need to institutionalize family policies focused on promoting a family culture to achieve the replacement birth rate. In addition, the current trends reveal that the future family models require the women integration in the working world and therefore family policies should focus on supporting a model that includes working women, as Sweden has been adopting since 1984. At the same time, family policies should solve the risk of new trends which leads to poverty situations that affects children development. Therefore, it is also necessary to determine measures to improve the understanding of a working family life.
\end{abstract}

\section{Keywords}

Poverty, Rate of Birth, Maternity, Family Policy, Expenditure Public

\section{Introduction}

The General Assembly of the United Nations, with the occasion of the twentieth anniversary of the international year of the family which takes place in the year 2104, has encouraged Member States to adopt new approaches in their family policies to achieve the objectives that the Economic Council and Social requested the Commission for Social Development provided for in resolution 2012/10 form in: (a) the eradication of poverty: the poverty of families and social exclusion; (b) full employment and decent work: the achievement of balance between work 
and family; and (c) social integration: the promotion of social integration and solidarity between generations.

There has been an X-ray of the current situation of the family from the data which were collected in The World Family Map (2013). Flaquer (2002) argues that the current family change can be reduced: a decline in the birth rate, incorporation of women to the world of work and increase of the marital breakdown. The increase in the number of extramarital births, without a cohabitation link and divorce, mainly in the Americas and Europe is changing the meaning of marriage. In most cultures, marriage has been considered as the main institution for conceiving and raising children (Chapais, 2008). However, this vision of the family as the basic cell of society (Crosnoe, 2004) has been transformed. Therefore, marriage is no longer the only possibility of intimate relationship between adults, becoming a majority option.

Some countries, such as Sweden, have achieved an increase in the birth rate through an institutionalization of the family policy. However, it is not enough with public funds to achieve the goals envisioned by the United Nations, so it is relevant to promote a family culture.

\section{Family X-Ray}

\subsection{Modes of Coexistence: Extensive, Two-Parent Family and Single-Parent Family}

There are three modes of coexistence: extensive, two-parent family and single-parent family. The economic crisis has affected family modalities. Puyana (2004) states that the extended family is a form of family organization useful to solve various social problems such as the survival of sectors of low income, lack of opportunities for future generations or the insufficient coverage of the social security system. Figure 1 confirms that in Asia the percentage of children living in an extended family exceeds $40 \%$, while in Central America and in the South it is 48\%. In Europe, the percentage does not reach 30\%.

According to data provided by The Word Family Map (2013) two-parent families in Asia account for $80 \%$. In Europe vary from 78\% in France to 89\% in Poland. On the other hand, the difference is wider in America countries with figures ranging from $50 \%$ in Colombia to $80 \%$ in Mexico. Also data from Africa varies, in South Africa is $36 \%$ while in Nigeria is 69\%. Regarding the rates of children living in single-parent households the highest correspond to North America and Europe with about one-fifth. In addition, the OECD (2011) says that this proportion will increase in many European countries towards 2030.

\subsection{Marriage and Cohabitation}

Data of the number of two married parent families differ across continents, since there is a decrease in the number of weddings in Europe, Africa and the Americas. Asian married adults between 18 to 49 years ranges between 77\% in Taiwan (Chinese) and 58\% in India. In Europe, it fluctuates from 37\% in Sweden to 53\% of Poland. In Africa,

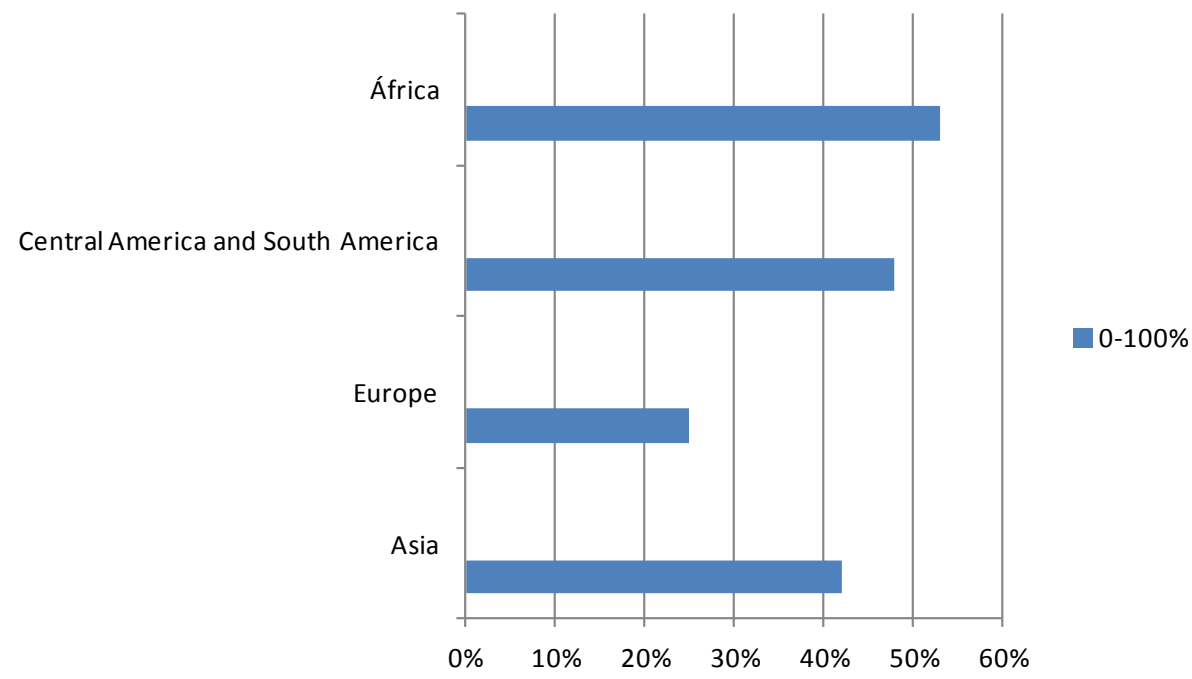

Figure 1. percentage of children living with extended family. Source: own elaboration (www.worldfamilymap.org/2013/). 
the variation is more pronounced from $30 \%$ in South Africa to $67 \%$ in Nigeria. On the other hand, in North America the oscillation is minimal because it ranges from 51\% in the USA to 58\% in Mexico. In South America the number of married adults does not exceed 40\%, highlighting Colombia with 19\% (The Word Family Map, 2013).

The reasons for cohabitation may be due to economic issues because it is a union model that could better adapt to times of crisis, since it entails less financial obligations (Castro \& Dominguez, 2008). In addition, the number of women is greater among which cohabit than among married women (Cunningham, 2005). Cohabitation is lower in countries with traditional customs in family life, such as in Asia. However, the oscillation is significant in Africa because it goes from $13 \%$ in South Africa up to $2 \%$ in Nigeria. Cohabitation is higher in Europe and South America ranging from 22\% in Bolivia to 39\% of Colombia (The Word Family Map, 2013).

\section{Eradication of Poverty: The Fight against Social Exclusion and Poverty of the Families}

Family poverty is one of the two major problems that must be addressed in the future (Behrman \& Sandham, 1994). In this sense, some studies claim that children growing up in poor environments suffer more problems of social, emotional, behavioral and physical health (Lempers, Clark-Lempers, \& Simons, 1989). According to The Global Gender Gap report in $2013^{1}$ single parental households that lack the father, poverty is higher because women may not always work and when they do, their salaries are lower. In addition, children from poor families are more likely to become poor (Flaquer, 2004) future parents.

\subsection{Absolute Poverty}

It is an indicator that measures the percentage of people living below the international poverty mean value established by the World Bank at US\$ 1.25 income per day. The World Bank has analyzed surveys conducted by the Governments statistical institutes and the LIS ${ }^{2}$. Figure 2 shows that absolute poverty in Asia rates vary from $0 \%$ in Malaysia to $42 \%$ in India.

However, the highest rates of extreme poverty are concentrated in African countries. In this sense, Figure 3 indicates that Nigeria has the highest rate of poverty estimated at $64 \%$ of the population.

Nevertheless, Figure 4 specifies that the poverty rate ranges in Central America and South America between Colombia and Nicaragua $18 \%$ and $2 \%$ of Costa Rica.

\section{Percentage of population living on less than $\$ 1.25 /$ day $A$ (for the most recent year available).}

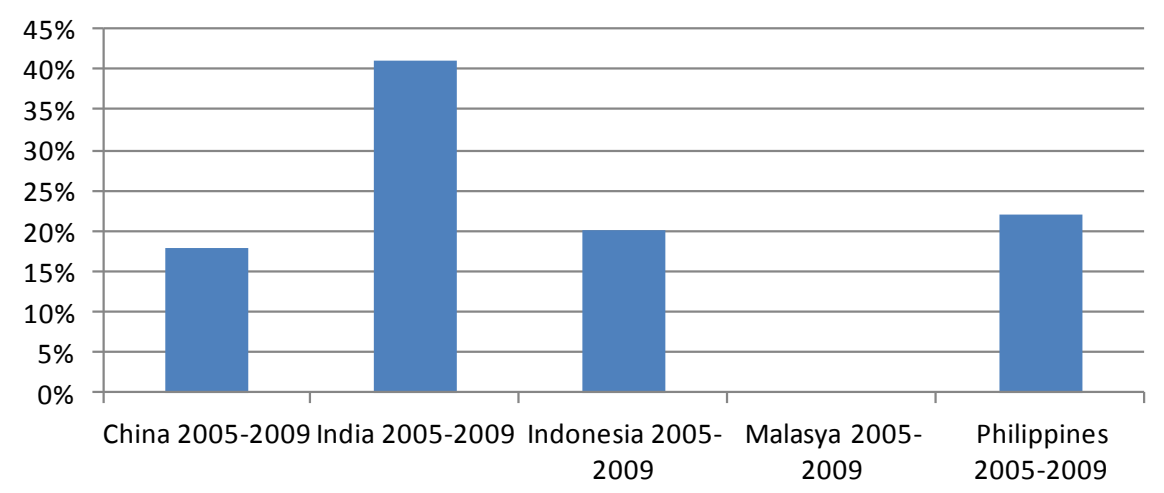

Figure 2. Percentage of population living on absolute poverty in some countries of Asia. Source: own elaboration (www.worldfamilymap.org/2013/).

1.http://www3.weforum.org/docs/WEF_GenderGap_Report 2013.pdf. Consulted on May 20, 2014.

${ }^{2}$ Luxembourg Income Studies (LIS) institution dedicated to the collection of data on the income and wealth of individuals in countries MIDs and highs. These data using LIS range from 2000 to 2010. 


\section{Percentage of population living on less than $\$ 1.25 /$ day $A$ (for the most recent year available).}

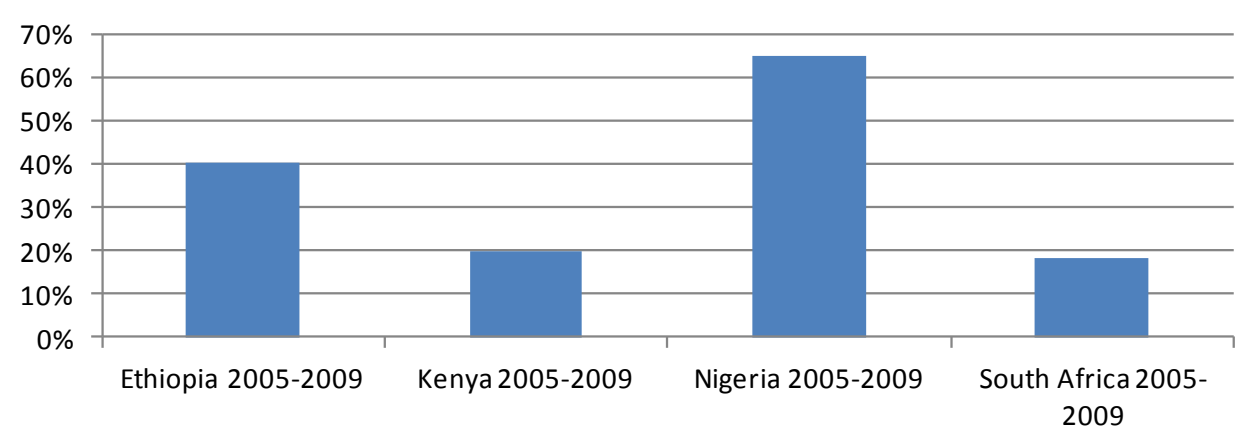

Figure 3. Percentage of population living on absolute poverty in some countries of Africa. Source: own elaboration (www.worldfamilymap.org/2013/).

\section{Percentage of population living on less than $\$ 1.25 /$ day $A$ (for the most recent year available).}

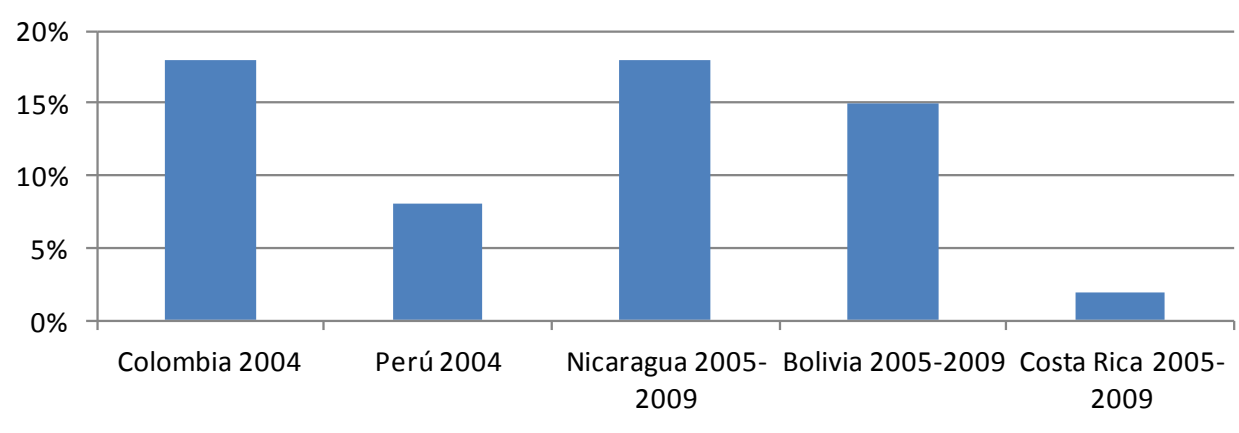

Figure 4. Percentage of population living on absolute poverty in some countries of Central America and South America. Source: own elaboration (www.worldfamilymap.org/2013/).

Therefore, the figures show that Nigeria is the country with greater absolute poverty rates.

\subsection{Relative Child Poverty}

The concept of relative poverty is an indicator that establishes the percentage of children living in households with income of less than the average income of each country. The correct measurement requires knowing the distribution of income. However, nor it is possible to establish a comparison between countries because the average income of each are different. The report Measurement of child poverty of the Innocenti Research Centre of $\mathrm{UNICEF}^{3}$ presents data on relative poverty. In general, selected Asian countries have low rates of relative child poverty. Rates are higher in the South American countries included in the study.

\footnotetext{
${ }^{3}$ Innocenti Research Centre of UNICEF, "Measurement of the poverty child: new tables qualifiers of the poverty child in los countries rich of the world" Innocenti Report Card 10 (Florence: Innocenti Research Centre of UNICEF, 2012). Data come from EU-SILC 2009, HILDA 2009, PSID 2007, Office of the Cabinet of Japan, gender equity directive (2011), and B. Perry, "Household Incomes in New Zealand: Trends in Indicators of Inequality and Hardship 1982 to 2010,” (Wellington, NZ: Ministry of Social Development, 2011).
} 


\section{Social Integration: The Promotion of Social Integration and Solidarity between the Generations}

Solidarity between the generations depends on the birth rate that also influences the families size and, therefore, child welfare because the children environment growing up without siblings is different that when they have them (Downey, 1995).

The replacement rate is 2.1 children who is met in the Americas, Africa and Asia. However, fertility has fallen significantly in South America during the last four decades, resembling those of North America and Oceania (Adsera \& Menendez, 2011). In Europe still remains below replacement level. In this sense, Table 1 indicates the fertility ratio of the most significant countries on every continent. It is important to know this data to understand Figures 5-8 which show the birth rate from single mothers in Asia (Figure 5), in Europe (Figure 6), in North, Central and South America (Figure 7) and Africa (Figure 8).

\section{Percentage of all live births to unmarried mothers}

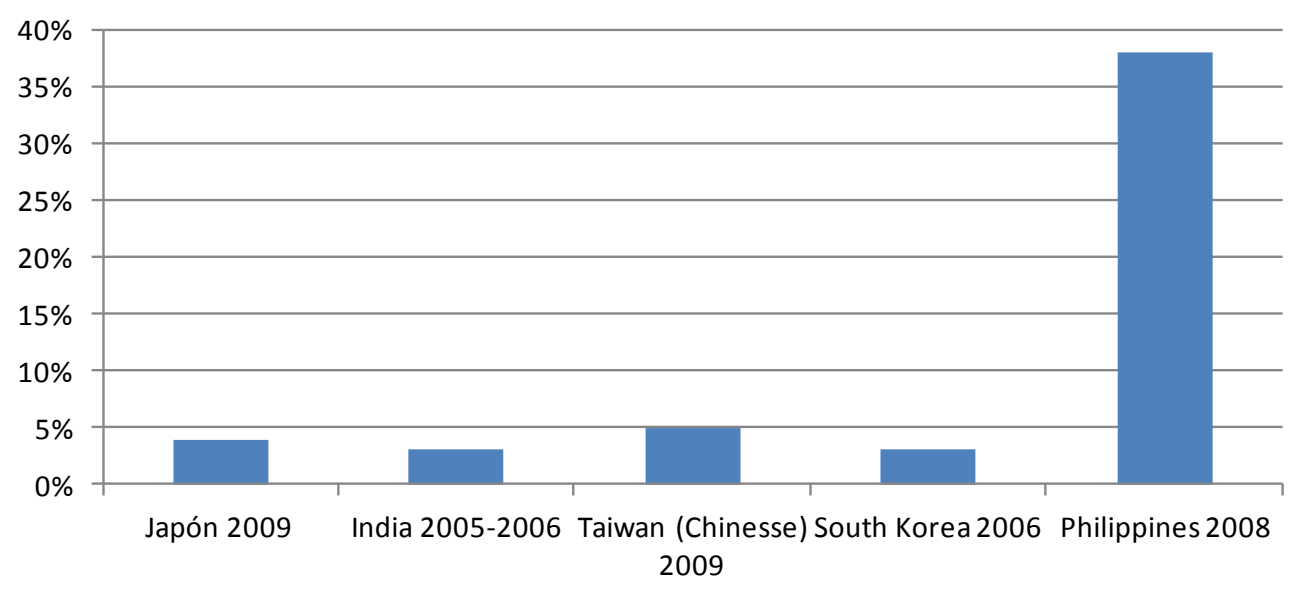

Figure 5. Maternity extramarital Asia (2005-2009). Source: own elaboration (www.worldfamilymap.org/2013/).

\section{Percentage of all live births to unmarried mothers}

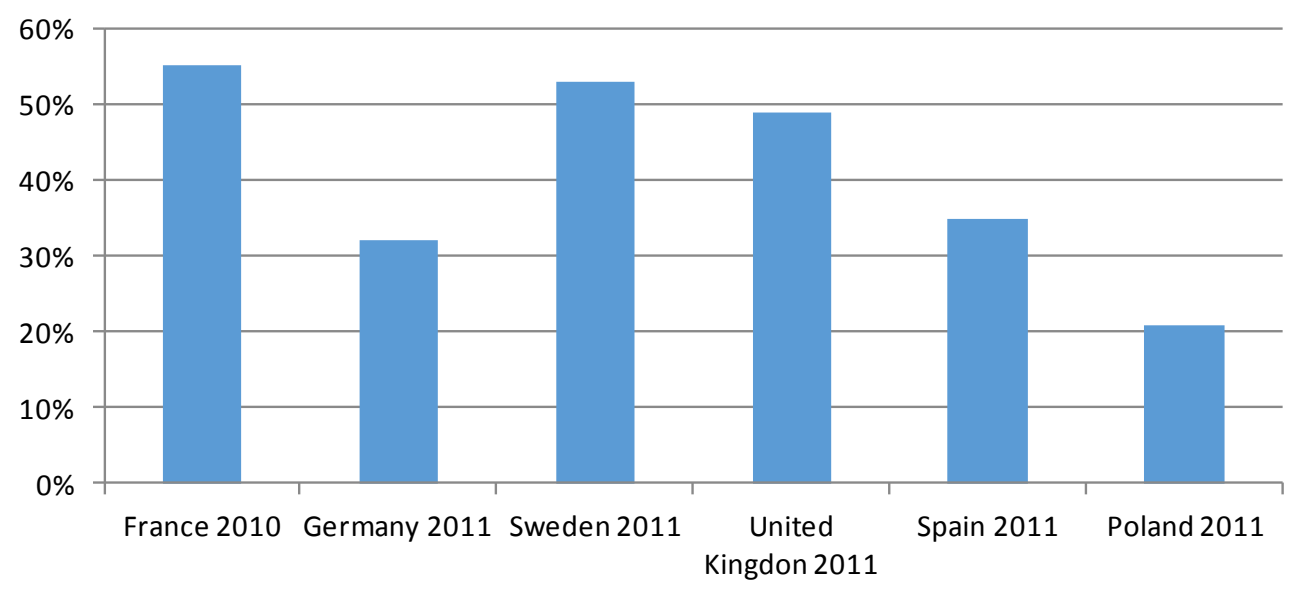

Figure 6. Extramarital maternity Europe (2010-2011). Source: own elaboration (www.worldfamilymap.org/2013/). 
Percentage of all live births to unmarried mothers

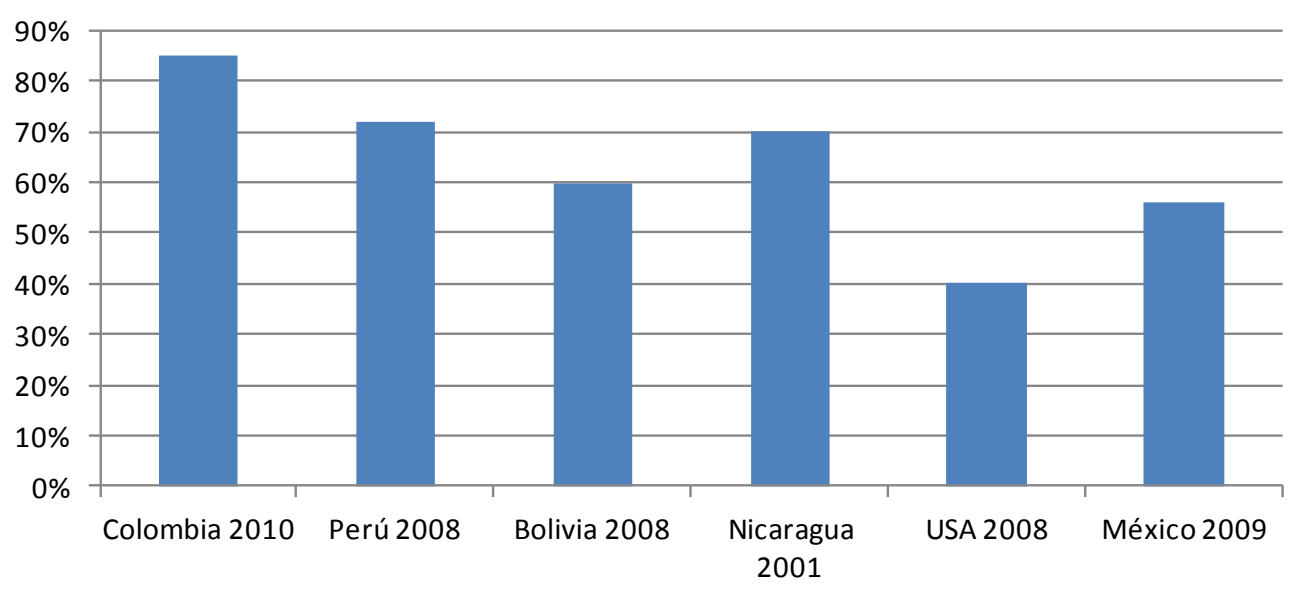

Figure 7. Extramarital-maternity leave, America Central, North and South (2001-2010). Source: own elaboration (www.worldfamilymap.org/2013/).

\section{Percentage of all live births to unmarried mothers}

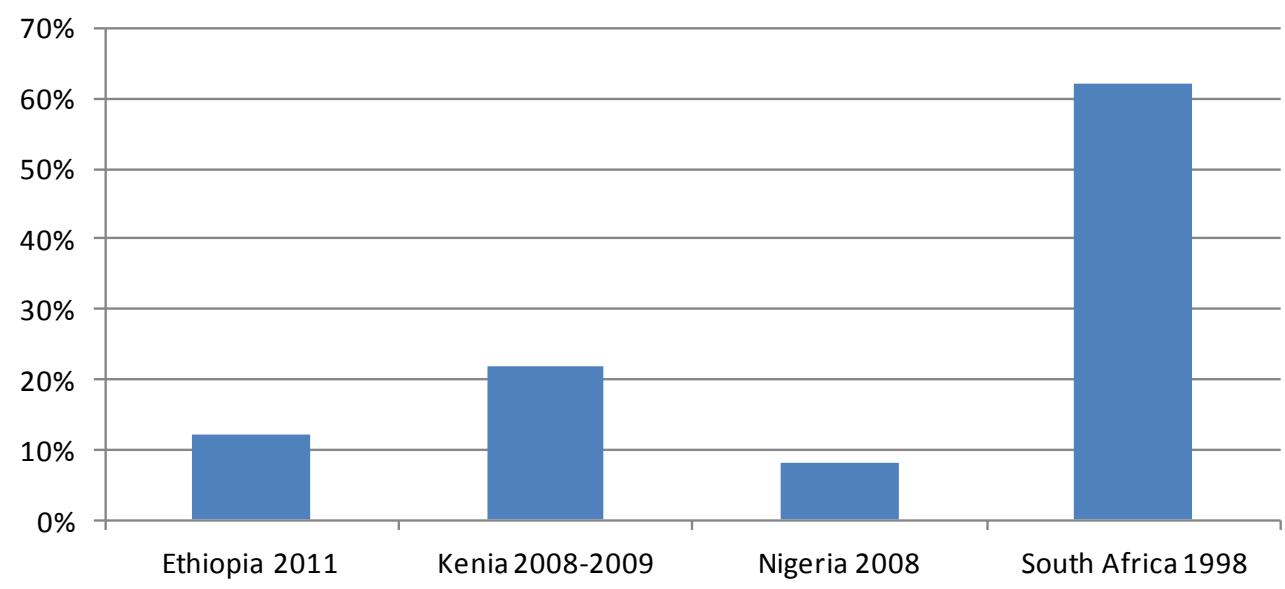

Figure 8. Africa extramarital maternity (1998-2011). Source: own elaboration (www.worldfamilymap.org/2013/)

Table 1. Number of children born per mother according to specific rates of fertility by age.

\begin{tabular}{|c|c|c|c|c|c|c|c|}
\hline \multicolumn{2}{|l|}{ Asia } & \multicolumn{2}{|c|}{ Europe } & \multicolumn{2}{|c|}{ North America, Central and South } & \multicolumn{2}{|c|}{ Africa } \\
\hline China & 1.2 & France & 2.0 & Colombia & 2.4 & Ethiopia & 4.2 \\
\hline India & 2.6 & Germany & 1.4 & Perú & 2.5 & Kenya & 4.7 \\
\hline Indonesia & 2.1 & Sweden & 1.9 & Bolivia & 3.3 & Nigeria & 5.5 \\
\hline Taiwan (Chinese) & 1.1 & R. Kingdom & 1.9 & Nicaragua & 2.6 & South Africa & 2.5 \\
\hline Malasya & 2.6 & Spain & 1.5 & USA & 1.9 & & \\
\hline Philippines & 3.1 & Poland & 1.4 & México & 2.3 & & \\
\hline
\end{tabular}


The percentage of all live births to unmarried mothers is relatively low in most Asian countries, except in the Philippines with a $37 \%$, as shows in Figure 5.

Figure 6 confirms that this percentage is more raised in the European countries. In France and Sweden more than the half of the births was born out of wedlock. Moreover, in these countries the average age of motherhood is lower than the average age of the first marriage (OECD, 2011).

According to The Word Family Map (2013) extramarital maternity rate is high in South America with more than 50\%, especially in Colombia with 85\%. In North America, approximately four in ten children are born out of marriage ranging from 27\% (Canada) to 55\% (Mexico). This is what the Figure 7 shows.

Figure 8 designates that in Africa the variation ranges from a minimum of $6 \%$ in Nigeria up to a maximum of $62 \%$ in South Africa.

In the event that the replacement rate is not achieved, the intergenerational solidarity is not guaranteed, that results in an increase of the extended households. According to Puyana (2004), these extended households cushion the effects of the economic crisis because they are shelter for single or young mothers.

\section{Full Employment and Decent Work: The Achievement of Balance between Work and Family}

The achievement of the objective of full employment is important to take into account changes in family patterns. Also relevant are the negative consequences of the lack of employment. For this reason, Vinokur, Price and Caplan (1996) pointed out that the financial and emotional pressure caused by the unemployment can cause depression and lower levels of couples' satisfaction, which affects the birth rate.

Table 2 presents data of children less than 18 years old living in households in which the household head is employed. However, these data doesn't indicate neither mode nor the employment duration. Neither indicates if both spouses work in two-parent households nor determines working hours.

The current family model implies an increase on working mothers. The effects of working mothers can be very positive if they have rewarding jobs, but become negative if their jobs produce stress and fatigue. However, the overloaded working mothers can have a negative about their children influence, especially if it is added to insecure or stressful jobs, but much worse is unemployment (Esping-Andersen, 2002). In the case of single mothers, there are three main possible sources of income: the non-resident parent, the labor market and the State (Flaquer, 2004).

\section{The Need for an Institutionalized Family Policy}

European countries have the highest levels of public expenditure on family benefits (Table 3), however, the birth rate is the lowest (Table 1). For this reason, a family policy that includes objectives, principles, and areas of intervention and concrete measures (Montoro, 2008) is required. In addition, Flaquer (2000) indicates that all family policies should answer three basic questions: what must be done about the low fertility rate? What should be done with the rise of family's poverty? And how to achieve a better reconciliation between work and family? Therefore, the areas of family policies action should be: "housing, labor, taxation, social action, education, entertainment, media, migration and demography” (Montoro, 2008: p. 66). However, family policy entails having a family model with the aim of achieving the replacement rate.

Table 2. Percentage of children under 18 in households in which the head is employed.

\begin{tabular}{cccccccc}
\hline Asia & & Europe & \multicolumn{3}{c}{ North America, Central and South } & \multicolumn{2}{c}{ África } \\
China 1990 & 94 & France 2005 & 80 & Colombia 2004 & 82 & Ethiopia & - \\
India 2004 & 89 & Germany 2007 & 88 & Perú 2004 & 90 & Kenya 1999 & 88 \\
Indonesia 2010 & 93 & Sweden 2005 & 90 & Bolivia 2001 & 71 & Nigeria & - \\
Taiwan (Chinese) 2005 & 97 & R. Kingdom 2004 & 79 & Nicaragua 2005 & 76 & South Africa 2008 & 45 \\
Malasya 2000 & 88 & Spain 2004 & 82 & USA 2010 & 71 & & \\
South Corea 2006 & 93 & Poland 2004 & 85 & México 2004 & 88 & & \\
\hline
\end{tabular}

Source: own elaboration (www.worldfamilymap.org/2013/). 
Table 3. Public expenditure on family benefits as a percentage of GDP (2007).

\begin{tabular}{cccccc}
\hline Asia & \multicolumn{3}{c}{ Europe } & North America, Central and South \\
\hline China & - & France & 3.7 & Colombia & - \\
India & - & Germany & 2.7 & Perú & - \\
Indonesia & - & Sweden & 3.4 & Bolivia & - \\
Japón & 1.3 & R. Kingdom & 3.6 & Nicaragua & - \\
Malaysia & - & Spain & 1.5 & USA & 1.2 \\
South Korea & 0.7 & Poland & 1.6 & México & 1.0 \\
\hline
\end{tabular}

Source: own elaboration (www.worldfamilymap.org/2013/).

The two European countries that have a clear institutionalization of the family policy are France and Sweden which are European countries that invest more GDP on family benefits according to Table 3. However, there is no relationship of public expenditure on family benefits with birth rate ${ }^{4}$ improvement.

Flaquer (2002) says that the first family policy measures aimed in European countries were money transfers, tax breaks and compensated maternity absences. However, these measures are insufficient to achieve the birth rate increase because the family policy should not only include economic or social measures, but should also promote a family culture (Lecaillon, 1995).

The best way to institutionalize a family policy is the creation of a central agency that is responsible for directing, promoting the family as an institution (Hertfelder, Martinez-Aedo, \& Velarde, 2011). However, Lecaillon (1995) states that few countries consider that the family is the support point for solving social problems.

An adequate family policy must discover the cause for the birth rate decline which may be due, according to Flaquer (2002), to a change in mentality or a reaction against the lack of economic resources. The increase in the level of non-marital fertility is a circumstance which modifies the traditional meaning of marriage in relation to the situation of women in the working world. Castro (2007) states that in Western countries with a greater plurality of forms of cohabitation, couples' breaks and births out of marriage and with highest levels of cohabitation are those who have a higher fertility rate; aspect that must be consider, because it involves a trend change.

However, in order to improve the birth rate, family policies must bear in mind that the trend, according to the current family X-ray is that the women incorporation into the labor market is increasing. The family policies developed in Sweden since1984 through the introduction of family measures, have managed to recover the birth rate, being the first objective the incorporation of women to work, enhancing a family model where the mother works. However, Lecaillon (1995) argues that women who develop a professional activity outside home have two children, but those who remain at home have more than 2.5 children on average. Therefore, an intervention with a clear family policy that contributes to birth rate growth is required.

In regards to measures against poverty, Flaquer (2004) establishes that there are two strategies to eradicate it in families: the provision of services and monetary transfers, noting that the second is the most effective. In contrast, the OECD (2011) argues that in order to improve the birth rate more effectively is necessary an investment in some form of child care as part of the support services as a whole to lower child care cost which has proven to be more effective than child bonus or tax relief. Therefore, Scandinavia has reduced child poverty to a minimum, through a combined strategy of transfers and support for working mothers (Flaquer, 2004). Consequently, an action is accurate in both lines. However, it is necessary to bear in mind that the increase in the divorce rate also has repercussions since it implies a loss of families' purchasing power, reaching $20 \%$ in the USA (Behrman \& Sandham, 1994).

The OECD (2011) confirms that investment in the family in European countries is intended above all, for financial support based on payments for licenses for maternity/paternity leave, subsidies for children and/or tax benefits for families. Another fundamental point is to promote the reconciliation between working life and work in order to best increase the birth rate (Flaquer, 2000).

\section{Summary and Conclusion}

An X-ray family has been explained by a clear trend of a greater cohabitation, more matrimonial breaks and a birth rate decrease because maternity age is delayed. Likewise, the economic crisis is sympathetic with the cohabitation 
modality that has increased the number of extensive families. According to the information contributed in The World Family Map (2013), a clear change is observed in the family conception, which has increased the birth of children out of marriage, in regime of cohabitation as well as in single-parent families.

Also, the family model has changed with respect to the women situation whose real incorporation into the working world is growing. This means that countries that have legislated to achieve an increase in the birth rate, such as Sweden, have opted for a model of working women. However, today the poverty rate affects more these family alternatives in comparison with the traditional two-parent family. However, these data are different among the countries included in The War Family Map study (2013).

Therefore, the achievement of the three objectives identified by the UN as an occasion of the twentieth anniversary of the international year of the family requires a reflection aligned with the family X-ray that takes into account new trends in the family model. This entails the need for an adequate family policy, not only to focus on economic measures, but also to recover the family culture, encouraging the increase in the birth rate, resolving, in addition, the circumstances of poverty that surround the new marriage forms. Therefore, the family policy must achieve the replacement rate, especially in Europe, which is needed to ensure inter-generational solidarity. Subsequently, reconciliation measures between work and family life also have a positive impact on the achievement of the birth rate increase.

\section{References}

Adsera, A., \& Menendez, A. (2011). Fertility Changes in Latin America in Periods of Economic Uncertainty. Population Studies, 65, 37-56. http://dx.doi.org/10.1080/00324728.2010.530291

Behrman, R. E., \& Sandham, Q. (1994). Children and Divorce: Overview and Analysis. The Future of Children, 1, 4-15. http://dx.doi.org/10.2307/1602474

Castro, T., \& Domínguez, M. (2008). Matrimonios “sin papeles”: Perfil sociodemográfico de las parejas de hecho en España según el Censo de 2001. Política y Sociedad, 45, 49-71.

Castro, T. (2007). Maternidad sin matrimonio. Nueva vía de formación de familias en España. Bilbao: Fundación BBVA.

Chapais, Fr. B. (2008). Primeval Kinship: How Pair Bonding Gave Birth to Human Society. Cambridge, MA: Harvard University Press.

Crosnoe, R. (2004). Social Capital and the Interplay of Families and Schools. Journal of Marriage and Family, 66, $267-280$. http://dx.doi.org/10.1111/j.1741-3737.2004.00019.x

Cunningham, M. (2005). Gender in Cohabitation and Marriage: The Influence of Gender Ideology on Housework Allocation over the Life Course. Journal of Family Issues, 26, 1037-1061. http://dx.doi.org/10.1177/0192513X04273592

Downey, D. (1995). When Bigger Is Not Better: Family Size, Parental Resources, and Children’s Educational Performance. American Sociological Review, 60, 746-761. http://dx.doi.org/10.2307/2096320

Esping-Andersen, G. (2002). A Child-Centered Social Investment Strategy. In G. Esping-Andersen et al. (Eds.), Why We Need a New Welfare State (pp. 26-67). Oxford: Oxford University Press. http://dx.doi.org/10.1093/0199256438.003.0002

Flaquer, L. (2000). Las políticas familiares en una perspectiva comparada. Barcelona: Fundación la Caixa.

Flaquer, L. (2002). Políticas Familiares en la Unión Europea. Barcelona: Institute de Ciències Politiques i Socials.

Flaquer, L. (2004). Monoparentalidad. Arbor, No. 702, 345-376. http://dx.doi.org/10.3989/arbor.2004.i702.571

Hertfelder, E. Martínez-Aedo, M., \& Velarde, L. (2011). La familia, desafío para una nueva política. Propuestas para una política pública con perspectiva de familia. Madrid: Instituto de Política Familiar.

Lecaillon, J. D. (1995). La familia como primera realidad económica. Madrid: Rialp.

Lempers, J. D., Clark-Lempers, D., \& Simons, R. (1989). Economic Hardship, Parenting, and Distress in Adolescence. Child Development, 60, 25-39. http://dx.doi.org/10.2307/1131068

Montoro, C. (2008). Objetivos, instrumentos y medidas de la política familiar. En C. Montoro, \& G. Barrios, Eds., Políticas familiares (pp. 114-127). Pamplona: Eunsa.

Puyana, Y. (2004). La familia extensa: Una estrategia local ante crisis sociales y económicas. Revista de Trabajo Social, 6, 77-86.

The Organisation for Economic Co-operation and Development (OECD) (2011). Doing Better for Families. Consulted on 3 June 2014. http://www.oecd.org/els/family/doingbetterforfamilies.htm

Vinokur, A. D. Price, R. H., \& Caplan, R. D. (1996). Hard Times and Hurtful Partners: How Financial Strain Affects Depression and Relationship Satisfaction of Unemployed Persons and Their Spouses. Journal of Personality and Social Psychology, 71, 166-179. 
Scientific Research Publishing (SCIRP) is one of the largest Open Access journal publishers. It is currently publishing more than 200 open access, online, peer-reviewed journals covering a wide range of academic disciplines. SCIRP serves the worldwide academic communities and contributes to the progress and application of science with its publication.

Other selected journals from SCIRP are listed as below. Submit your manuscript to us via either submit@scirp.org or Online Submission Portal.
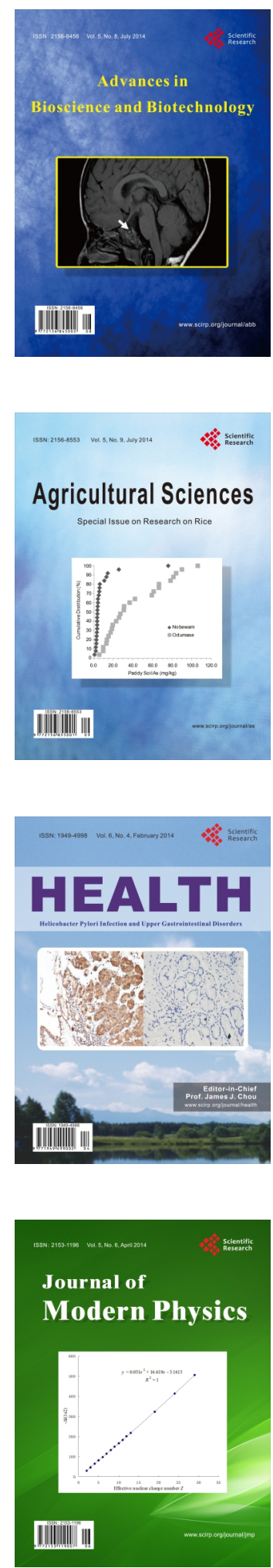
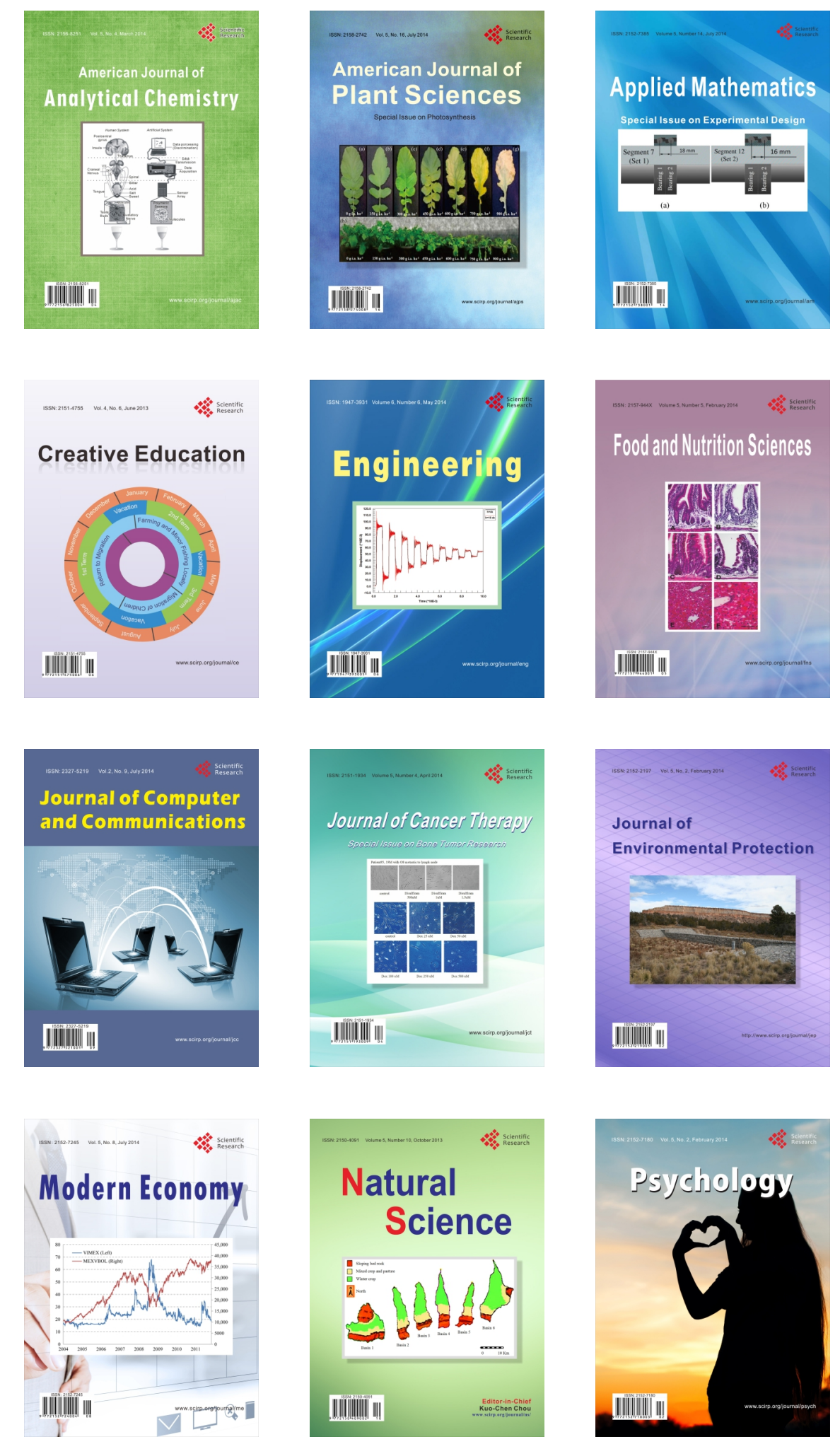